\title{
THE DESIGN OF THE FRACTAL POETICAL MODEL OF THE WORLD (BASED ON THE BRITISH POETRY OF THE XX -XXI ${ }^{\mathrm{ST}}$ CENTURIES)
}

\author{
Moskvichova O. A.
}

\author{
To see a World in a grain of sand, \\ And a Heaven in a wild flower, \\ Hold Infinity in the palm of your hand, \\ And Eternity in an hour. \\ W. Blake "Auguries of Innocence"1
}

\section{INTRODUCTION}

In the mathematics, in the computer science, in the fractal geometry, in the theory of systems, and in the synergetics 'the fractal (from the Latin 'fractus' - 'to break, to destroy') - is identified as the object that is characterized by the fractional structure having the hierarchical level of the organization; as the endless geometrical figure every fragment of which is repeated in the reduced $s^{2}{ }^{2}$. In the academic scientific world the leading role in the generation of the theory of fractals belongs to the mathematics because fractals have been identified by the mathematician Benoit B. Mandelbrot in his scientific research "The Fractal Geometry of Nature" ${ }^{\text {. }}$ Benoit B. Mandelbrot generated fractals by means of the mathematical and computer calculations and the researches of the coastline of Great Britain. Fractals have been investigated deeply in the mathematics but this term belongs also to the sphere of the synergetics, the science that comprises the physics and the mathematics, and has been integrated into the linguistics being the interdisciplinary direction of the scientific researches in the aspect of which are investigated processes of the transition from the chaos to the order and vice versa in the open nonlinear spheres of the different nature ${ }^{4}$. In the article we are served by the dominant role of the exploration of the fractality in the mathematics because in the process of the constructing of the

\footnotetext{
${ }^{1}$ Blake W. The Selected Poems. London : Wordsworth Poetry Library, 2019. 384 p.

2 Деменок С.Л. Просто фрактал. Санкт-Петербург : Страта, 2018. 308 с.

${ }^{3}$ Mandelbrot B.B. The Fractal Geometry of Nature. New York : W.H. Freemanand Company, 1982. $470 \mathrm{p}$.

${ }^{4}$ Деменок С.Л. Суперфрактал. Санкт-Перербург : Страта, 2018. 228 с.
} 
fractal poetical model of the world we rely on the postulates of the mathematical modelling of fractals.

The aim of the article is to describe the process of the modelling of the fractal poetical model of the world in the linguistic and the cognitive aspects on the basis of the British poetry of the XIX - XXI ${ }^{\text {st }}$ centuries.

The object of the scientific research is the fractal poetical model of the world in the British poetry of the XIX - XXI ${ }^{\text {st }}$ centuries. The subject - the cognitive and the fractal potential of literary concepts ${ }^{5}$, conceptual tropes, frames and emergent conceptual blends as verbal means of the modelling of the fractal poetical model of the world on the basis of the British poetical texts of the romantic, the modern and the postmodern periods.

The material of the investigation is presented by the British poetry of the XIX $-\mathrm{XXI}^{\text {st }}$ centuries in the total amount of 3628 poetical texts (4832 pages). For the illustration of the design of the fractal poetical model of the world have been chosen the brightest examples (490 poetical texts on 267 pages).

The methodology of the modelling of the fractal poetical model of the world is polydisciplinary conditioned by the combination of the interpretational, the textual, the descriptive, the semantic, the component, the linguistic, the stylistic, the cognitive, the poetical, the mathematical, the fractal, the geometrical methodology.

\section{The illumination of fractals in the modern scientific paradigm}

The founder of the theory of the fractality Benoit B. Mandelbrot has identified the term 'the fractal' from the Latin words 'frangere' (to break') and 'fractus' ('ruptured, discrete, fractional'). The word is identical to the English 'fracture' ('the rapture') and 'fraction' ('the fraction'). Except the meaning 'fractional' (in words 'the fraction' and 'the refraction') the word 'fractus' means 'the wrong-shaped ${ }^{6}$. Thus, Benoit B. Mandelbrot has modeled the definition of the identified by him term 'the fractal as for the algorithm and the association from the English 'FRACTionAL'. Even graphically Benoit B. Mandelbrot has written the word 'FRACTAL' from 'FRACTionAL' by means of capital letters in the way the cognitive scientists write identified and verbalized concepts. The conceptual sphere in the field of the cognitive linguistics is graphically represented by the linguists in the similar way to the Circular Apollo Fractal (e.g., (Fig. 1)). Thus, we surmise the existence of the connection between the cognitive linguistics and the fractional mathematical theory in the graphical way.

\footnotetext{
${ }^{5}$ Nikonova V., Boyko Y. Gender-specific emotivity of Victorian female prose from a multidimensional perspective. In Lege artis. Language yesterday, today, tomorrow. 2019. Vol. IV (1). P. 47-82.

${ }^{6}$ Деменок С.Л. Просто фрактал. Санкт-Перербург : Страта, 2018. 308 с.
} 

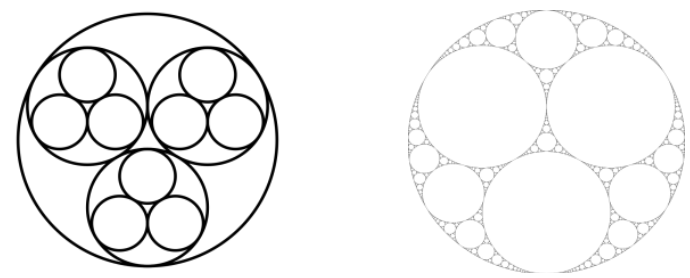

Figure 1. The Circular Apollo Fractals

Fractals or the mathematical and the geometrical monsters have changed the mathematics of the end of the $X^{\text {th }}$ century and after their multidisciplinary integration into different scientific spheres lots of terms and forms have been identified by the scientists in the fractional and the mathematical way. Benoit B. Mandelbrot has summarized different types of fractals, has identified the ways of the fractional computer calculation that have been integrated into the modern fractional computer graphics (e.g., (Fig. 2; Fig. 3; Fig. 4)) ${ }^{7}$.
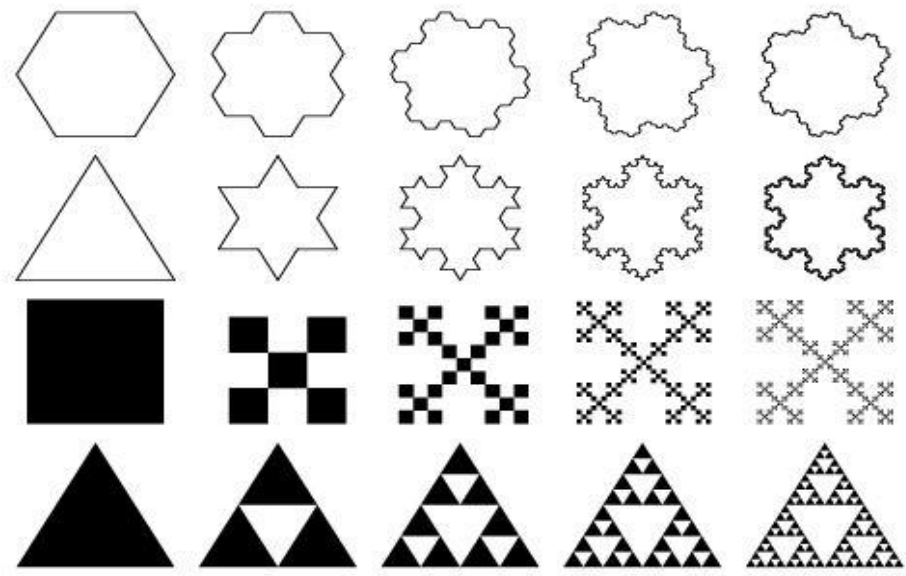

Figure 2. Types of fractals

${ }^{7}$ Mandelbrot B.B. The Fractal Geometry of Nature. New York : W.H. Freemanand Company, 1982. $470 \mathrm{p}$. 

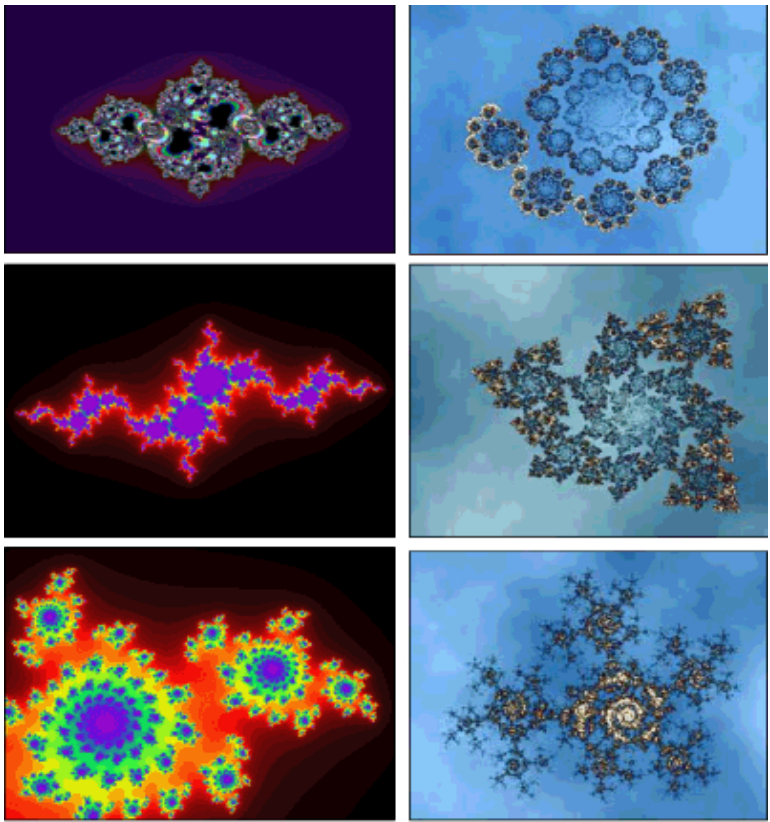

Figure 3. Types of fractals in the computer graphics

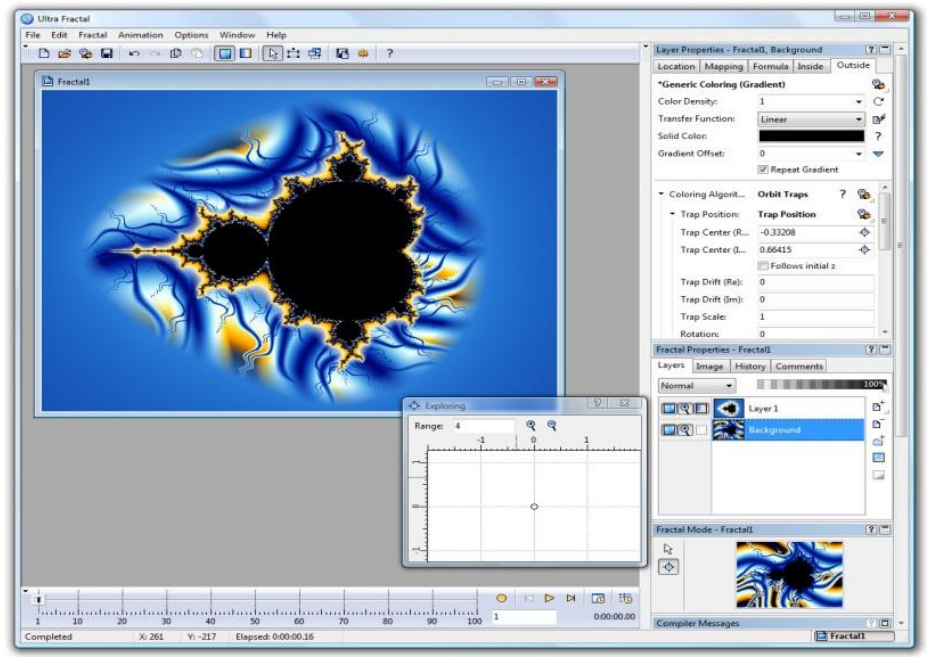

Figure 4. The computer calculation of fractals in the computer graphics 
Benoit B. Mandelbrot has stated that every self-similar fractal element is never-ending because structurally every fractal consists from the smallest or the fractional elements the modelling of which is ruled by the previous elements of the fractal. The fractal is the self-similar and the never-ending unity, the connection between elements of which is determined by the connection between all the elements of the fractal. The construction of the fractal is strict and mathematically determined because every small element of the fractal is the simplified version of the whole fractal. The process of the modelling of the fractal is ruled by the repeated repetition of the analogical mathematical operations - iterations. Fractal iterations are recursive, the final stage of the previous element of the fractal is the beginning of the new stage of the fractal modelling - the iterational fractal process. The fractal modelling is the endless process because fractals have the beginning but don't have the ending and the final stage of the modelling ${ }^{8}$.

\section{The modelling of the fractal poetical model of the world}

Extrapolating the methodology of the linguistic, the poetical, the cognitive analysises of the poetry and considering the results of the fractal modelling in the mathematics, in the fractal geometry, in the synergetics, in the theory of systems we propose the methodology of the modelling of the fractal poetical model of the world on the basis of the British poetry of the XIX-XXI ${ }^{\text {st }}$ centuries in the linguistic and the cognitive perspectives.

Thus, the fractal poetical model of the world is characterized by the complex structure, the starting point of it's constructing is the strange / the circular / the cyclic fractal attractor (from the Latin 'attrahere - 'to attract'; from the English 'to attract $)^{9}$. The fractal attractor is the starting point of the fractal modelling that is stable and attracts to itself all the trajectory of the whole fractal system or the fractal model. Structurally, in the aspect of the fractal geometrical modelling, the fractal attractor comprises from the central node around which, in the spiral form, are pulverized trajectories of the fractal that never intersect and are concentrated around the central node of the attractor. The strange fractal attractor in the fractal modelling is the trajectory of the fractal orbit that makes possible the fractal modelling to get started in such a way: the central node of the strange fractal attractor $\rightarrow$ the cycle $\rightarrow$ the fractal (e.g., (Fig. 5)).

\footnotetext{
${ }^{8}$ Деменок С.Л. Суперфрактал. Санкт-Перербург : Страта, 2018. 228 с.

${ }^{9}$ Деменок С.Л. Суперфрактал. Санкт-Перербург : Страта, 2018. 228 с.
} 

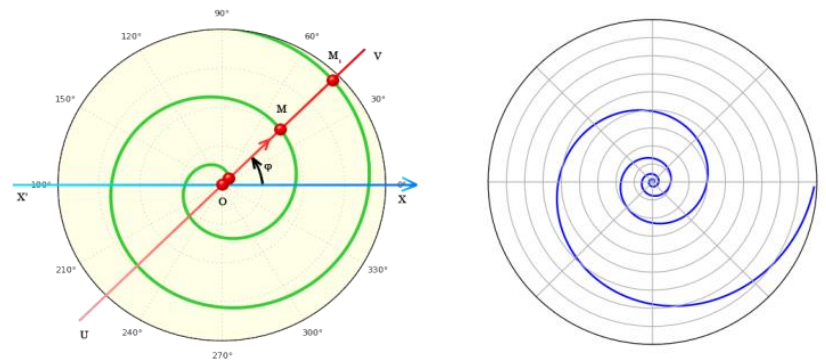

Figure 5. The trajectory of the fractal modelling from the central node
of the strange fractal attractor to the cycle and to the fractal

Integrating the theoretical aspects of the fractal modelling and taking into consideration the actuality of the term 'the strange fractal attractor' in the aspect of the fractal constructing while the modelling of the fractal poetical model of the world we propose to understand under the central no de of the attractor the literary concept or literary concepts that are identified by us in the British poetry of the $\mathrm{XIX}-\mathrm{XXI}{ }^{\mathrm{st}}$ centuries. The literary concept in the cognitive linguistics and the cognitive poetics is the basic element of the fractal conceptual model of the world that includes linguistic and extralinguistic aspects determined by historical and cultural traditions of the romantic, the modern and the postmodern periods in Great Britain.

The central node of the fractal poetical model of the world is the literary concept / literary concepts. According to the trajectory of the orbit of the strange fractal attractor the dynamics of the fractal modelling of the poetical model of the world we outline in such an order: literary concepts $\rightarrow$ the basic conceptual tropes (the conceptual metaphor, the conceptual metonymy, the conceptual oxymoron, the conceptual metamorphosis $\left.{ }^{10}\right) \rightarrow$ the frame mode of the fractal poetical model of the world (frames) $\rightarrow$ the integrated mode of the fractal poetical model of the world (emergent conceptual blends).

The article is concentrated around the identification of the literary concepts and the basic conceptual tropes in the British poetry of the XIX$\mathrm{XXI}^{\text {st }}$ centuries and the frame and the integrated modes of the fractal poetical model of the world will be represented in the next publications of the author of the article.

The deep nature of the fractal poetical model of the world is determined by it`s complicated linguistic and cognitive aspects that are explained by the

10 Москвичова О.А. Еволюція метаморфози в англійському поетичному мисленні : монографія. Херсон : Айлант, 2015. 220 с. 
combination in the fractal poetical model of the world micro-segments (literary concepts), macro-segments (basic conceptual tropes), frames and the emergent conceptual blends in one fractal unity. We define the fractal poetical model of the world as the complex linguistic, cognitive and fractal construct that comprises from segments modelled according to the iterational and integrated methodology of the linguistic, the poetical, the cognitive analysises with the deployment into the fractal net of the conceptual senses filled with frames and conceptual blends.

In the cognitive linguistics has been proved that the fractal 'iteration' (from the Latin 'iteration' - 'to repeat') is the process of the multiple repetition of the analogous structure or the step as for the analogy with the previous repetitive operation. The fractal 'recursion' (from the Latin 'recursio - 'the returning') - the process of the repetition according to the certain algorithm or the formula when the starting cycle is the result of the previous cycle. The fractal self-similarity is the fractal peculiarity of the whole fractal system in which the structural organization of an element is repeated completely or partially according to the structure of other elements of the whole fractal system ${ }^{11}$.

In the article we propose the fractal modelling of the fractal poetical model of the world based on the computer fractal modelling the fundamental fractal of which is the Mandelbrot Fractal. But our investigation is added by the linguistic and the cognitive aspects of the fractal poetical model of the world based on the results of the scientific research on the basis of the British poetry of the XIX-XXI ${ }^{\text {st }}$ centuries from the point of the cognitive linguistics and the cognitive poetics. In such a way our investigation is multidisciplinary or the subdisciplinary combining the fractal theory in the mathematics and in the fractal geometry integrated into the sphere of the cognitive linguistics and the cognitive poetics.

We have stated that the starting point of the modelling of the fractal poetical model of the world is the literary concept or literary concepts identified by us in the British poetry of the XIX-XXI ${ }^{\text {st }}$ centuries. The hierarchy of the verbalized literary concepts is congregated by us into the micro-segment of the fractal poetical model of the world. We design the micro-segment of the fractal poetical model of the world on the basis of the graphic modelling of the Mandelbrot Fractal that consists from three concentric circles. The main circle of the mentioned fractal is the main cardioid and the additional circles are the copies of the main cardioid circle. The number of additional circles may be endless (e.g., (Fig. 6)).

${ }^{11}$ Бистров Я.В. Біографічний наратив у лінгвокогнітивному вимірі (на матеріалі англомовної прози XX - початку XXI століть) : дис. ... д-ра філ. наук : 10.02.04 / Київський нац. лінгвістичний ун-т. Київ, 2016. 460 с. 


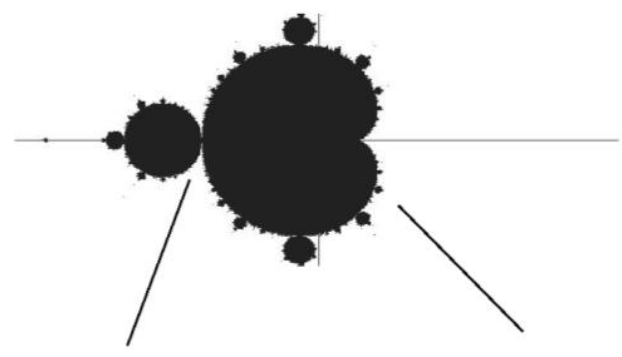

additional circles

the main cardioid circle

\section{Figure 6. The graphic modelling and the structure of the Mandelbrot Fractal}

According to such a graphic design of the structure of the Mandelbrot Fractal we model the micro-segment of the fractal poetical model of the world that is impregnated by the identified by us literary concepts on the bas is of the British poetry of the XIX-XXI ${ }^{\text {st }}$ centuries. The main cardioid circle of the microsegment of the fractal poetical model of the world (1) is the presentive and the sensual and is impregnated by the aptly identified literary concepts in the British poetry of the XIX-XXI ${ }^{\text {st }}$ centuries. The first additional circle of the fractal microsegment of the fractal poetical model of the world (2) is denominated by us the typology of the conceptual and the semantic approximations on the micro-level of the micro-segment and is nominated by us the imaginative and the associative circle. This circle we impregnate by the literary concepts containing the information of the as sociative type. The next additional circle (3) is the circle of the conceptual and the semantic deviations and is impregnated by rare literary concepts and is identified by us as the semantic circle (e.g., (Fig. 7)).

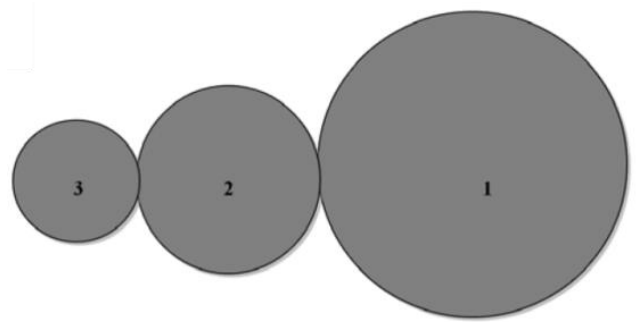

Figure 7. The fractal modelling of the micro-segments of the fractal poetical model of the world

(1-the presentive and the sensual micro-segment of the typology of the fractal iterations of the self-similar literary concepts; 2 - the conceptual and the semantic micro-segment of the typology of the conceptual and the semantic approximations; 3 - the semantic microsegment of the typology of the conceptual and the semantic deviations) 
In the analogical way we design the macro-segment of the fractal poetical model of the world that is repleted by the reconstructed by us conceptual tropes (the conceptual metaphor, the conceptual metonymy, the conceptual oxymoron, the conceptual metamorphosis (e.g., (Fig. 8)).

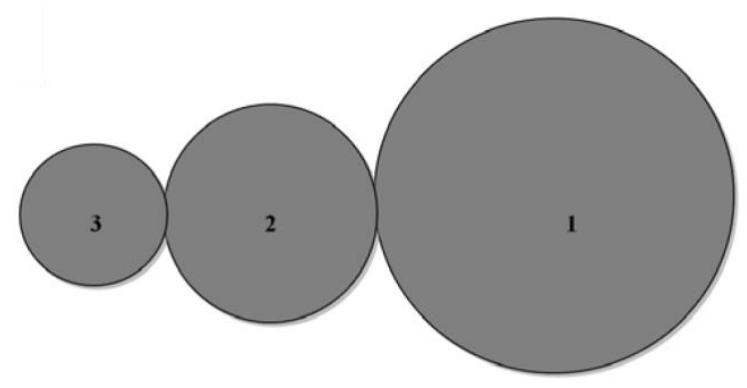

Figure 8. The fractal modelling of the macro-segments of the fractal poetical model of the world

As we have been mentioned the fractal recursion is the process when the previous step of the fractal modelling is the starting point of the design of the next fractalstep. The Mandelbrot Fractal in the fractal geometry is the starting point or the reservoir for the further fractal modelling the variety of which is identified in mathematics and the fractal geometry (e.g., (Fig. 9; Fig. 10)).

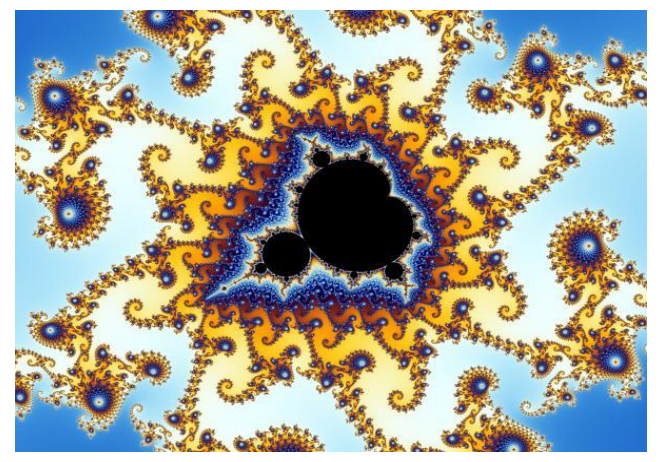

Figure 9. The computer design of various fractals from the reservoir of the Mandelbrot Fractal 


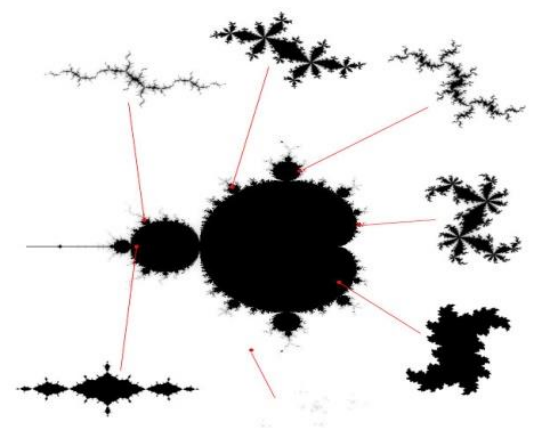

Figure 10. The modification of various fractals from the reservoir of the Mandelbrot Fractal

In our scientific investigation the micro-segment of the fractal poetical model of the world is transformed into the segment of the conceptual senses of the frame mode fulfilled by frames. The macro-segment of the fractal poetical model of the world is transformed into the net of the conceptual senses of the integrated mode fulfilled by emergent conceptual blends. Frames and conceptual blends are modelled according to linguistic and cognitive operations and procedures existing in the cognitive linguistics and the cognitive poetics and will be presented by us in the next articles (e.g., (Fig. 11)).

The micro-segment of the fractal poetical model of the world

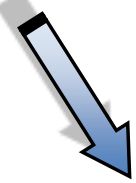

The frame mode of the fractal poetical model of the world (frames)
The macro-segment of the fractal poetical model of the world

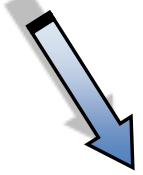

The integrated mode of the fractal poetical model of the world (conceptual blends)

Figure 11. The transformation of micro- and macro-segments of the fractal poetical model of the world into integrated modes

Graphically integrated modes will be designed by us as various types of fractals. Thus frames will be modelled as the Fractal 'Snowflake', conceptual blends - as the Fractal `Square` (e.g., (Fig. 12)). 

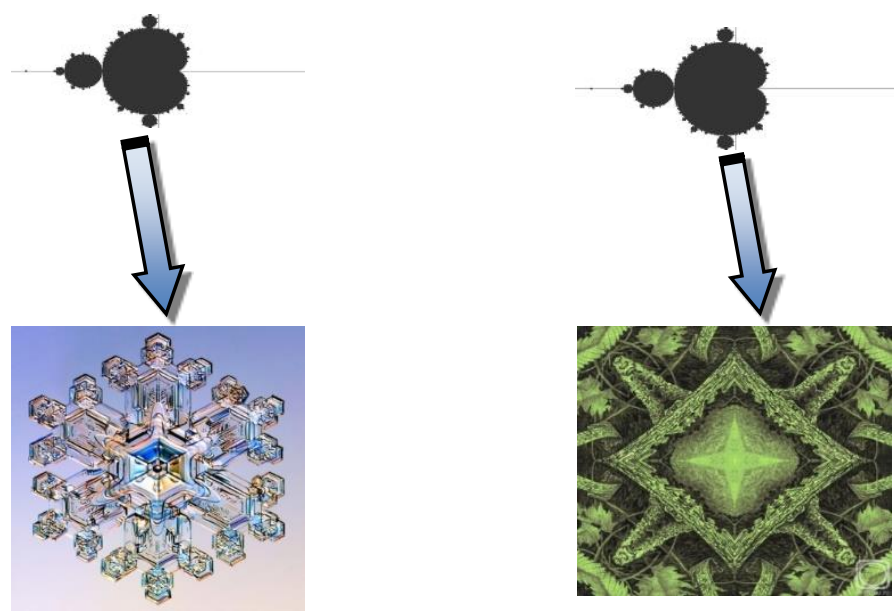

Figure 12. The graphic transformation of micro- and macro-segments of the fractal poetical model of the world into integrated modes

The fractal iteration in the process of the modelling of the fractal poetical model of the world is characterized by us as main procedures of the identification and the reconstruction of literary concepts and conceptual tropes existing in the cognitive linguistics and in the cognitive poetics. And the whole fractal poetical model of the world, consisting frommicro- and macrosegments, integrated frames and conceptualblends modes will be graphically modelled as the Dragon Fractal of Harter-Heighway or the Fractal Julia and will be presented in the next scientific publications of the author (e.g., (Fig. 13)).

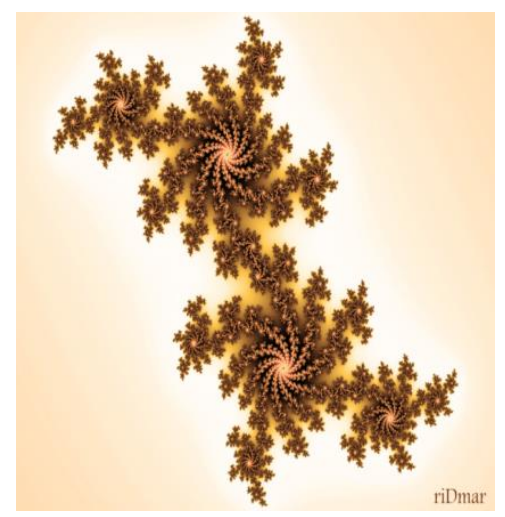

Figure 13. The Dragon Fractal of Harter-Heighway or the Fractal Julia 
In the result of the investigation of the realization of the designed fractal poetical model of the world in the British poetry of the XIX-XXI ${ }^{\text {st }}$ centuries we propose the summarizing results that form the basis for the construction of the micro- and the macro-segments of the fractal poetical model of the world. The material of the scientific doctoral research of the author in the doctoral dissertation on the title "The fractal poetical model of the world in the linguistic and the cognitive survey (on the material of the British poetry of the XIX-XXI ${ }^{\text {st }}$ centuries) includes the British poetry of the mentioned centuries in the total amount of 3628 poetical texts (4832 pages). From the analyzed poetry the author of the article has chosen the brightest examples (490 poetical texts (267 pages)). The results of the investigation are illustrated by the author in the doctoral dissertation on the basis of 230 poetical texts. In the article we represent the summarizing results in tables because the whole amount of the poetical texts analyzed in the dis sertation comprises 93 pages and can`t be illus trated in the article.

As we have mentioned the microsegment of the fractal poetical model of the world is represented by the identified literary concepts in the British poetry of the XIX-XXI ${ }^{\text {st }}$ centuries. We have stated that micro- and macrosegments of the fractal poetical model of the world are designed by us on the basis of the Mandelbrot Fractal. Both micro- and macrosegments consist of tree circles, such as:

- the first main cardioid circle (the presentive and the sensual) - (1);

- the second additional circle (the conceptual and the semantic approximations) - (2);

- the third additional circle (the semantic deviations) - (3).

Graphically both micro- and macro segments we design according to the model of the Mandelbrot Fractal (e.g., (Fig. 14)).

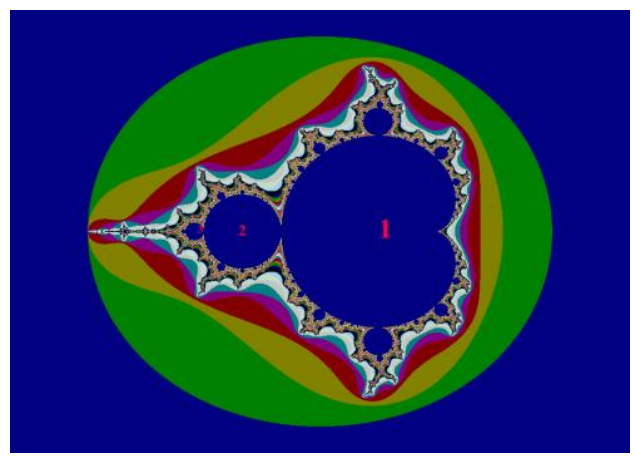

Figure 14. The graphic design of micro- and macrosegments of the fractal poetical model of the world 
The hierarchy of the literary concepts identified in the British poetry of the modern period that fill the first main circle of the microsegment of the fractal poetical model of the world is presented in the following table (numbers $1-3$ ). The second additional circle is filled by the literary concepts (numbers $4-6$ ). The third additional circle is filled by the literary concepts (numbers $7-13$ ) (table 1).

Table 1

Literary concepts identified

in the British poetical texts of the modern period

\begin{tabular}{|c|c|c|}
\hline \multicolumn{2}{|c|}{$\begin{array}{c}\text { The hierarchy } \\
\text { of the literary concepts }\end{array}$} & $\begin{array}{c}\text { The total amount } \\
\text { of the realization (\%) }\end{array}$ \\
\hline 1. & DEATH & $8(25 \%)$ \\
\hline 2. & LOVE & $6(19 \%)$ \\
\hline 3. & PERSONALITY & $5(16 \%)$ \\
\hline 4. & DREAM & $2(6 \%)$ \\
\hline 5. & LIFE & $2(6 \%)$ \\
\hline 6. & GOD & $2(6 \%)$ \\
\hline 7. & FLOWER & $1(3 \%)$ \\
\hline 8. & NOTHING & $1(3 \%)$ \\
\hline 9. & MAGIC & $1(3 \%)$ \\
\hline 10. & RESURRECTION & $1(3 \%)$ \\
\hline 11. & FEELING & $1(3 \%)$ \\
\hline 12. & WORLD & $1(3 \%)$ \\
\hline 13. & TIME & The total amount -32. \\
\hline \multicolumn{3}{|c|}{$\begin{array}{c}\text { Numbers } 4-6-6(19 \%) . \\
\text { Numbers } 7-13-7(22 \%) .\end{array}$} \\
\hline \multicolumn{2}{|c|}{} \\
\hline
\end{tabular}

The hierarchy of the conceptual metaphors identified in the British poetry of the modern period that fill the first main circle of the macrosegment of the fractal poetical model of the world are presented in the following table (number 1). The second additional circle is filled by the conceptual metaphors (numbers $2-3$ ). The third additional circle is filled by the conceptual metaphors (numbers $4-16$ ) (table 2). 
Conceptual metaphors reconstructed in the British poetical texts of the modern period

\begin{tabular}{|c|c|c|}
\hline \multicolumn{2}{|r|}{$\begin{array}{c}\text { The hierarchy } \\
\text { of the conceptual metaphors }\end{array}$} & $\begin{array}{c}\text { The total amount } \\
\text { of the realization }(\%)\end{array}$ \\
\hline 1 . & LOVE IS DEATH & $4(19 \%)$ \\
\hline 2. & PERSON IS A CONTAINER & $2(10 \%)$ \\
\hline 3. & LOVE IS SLEEP & $2(10 \%)$ \\
\hline 4. & A PERSON IS A LIGHT & $1(5 \%)$ \\
\hline 5. & $\begin{array}{l}\text { A FLOWER (A ROSE) IS A LIVING } \\
\text { BEING }\end{array}$ & $1(5 \%)$ \\
\hline 6. & NOTHING IS A CONTAINER & $1(5 \%)$ \\
\hline 7. & DREAM IS THE SCENT & $1(5 \%)$ \\
\hline 8. & MAGIC IS A FEELING & $1(5 \%)$ \\
\hline 9. & LIFE IS ALL (A CONTAINER) & $1(5 \%)$ \\
\hline 10. & GOD IS A HUMAN & $1(5 \%)$ \\
\hline 11. & $\begin{array}{c}\text { ARCHANGELS AND ANGELS ARE } \\
\text { FOOLS (SOLDIERS) }\end{array}$ & $1(5 \%)$ \\
\hline 12. & LIFE IS AN EMBROIDERY & $1(5 \%)$ \\
\hline 13. & LOVE IS AN EMBROIDERY & $1(5 \%)$ \\
\hline 14. & DREAMS ARE THE EMBROIDERY & $1(5 \%)$ \\
\hline 15. & $\begin{array}{l}\text { THE WORLD IS THE WORLD OF } \\
\text { DREAMS }\end{array}$ & $1(5 \%)$ \\
\hline 16. & GOD IS UP & $1(5 \%)$ \\
\hline \multicolumn{3}{|c|}{$\begin{array}{c}\text { The total amount }-21(100 \%) \text {. } \\
\text { Numbers } 1-4(19 \%) . \\
\text { Numbers } 2-3-4(19 \%) \\
\text { Numbers } 4-16-13(62 \%) \\
\end{array}$} \\
\hline
\end{tabular}

The second additional circle is filled by the conceptual metonymies (table 3).

Table 3

Conceptual metonymies reconstructed in the British poetical texts of the modern period

\begin{tabular}{|c|c|c|}
\hline \multicolumn{2}{|c|}{$\begin{array}{c}\text { The hierarchy } \\
\text { of the conceptual metonimies }\end{array}$} & $\begin{array}{c}\text { The total amount } \\
\text { of the realization (\%) }\end{array}$ \\
\hline 17. & NAMES STAND FOR MEN & $1(100 \%)$ \\
\hline \multicolumn{2}{|c|}{ The total amount -1.} \\
\hline
\end{tabular}

The second additional circle is filled also by the conceptual metamorphosises and the conceptual oxymorons (table 4). 
Conceptual metamorphosises reconstructed in the British poetical texts of the modern period

\begin{tabular}{|c|c|c|}
\hline \multicolumn{2}{|r|}{$\begin{array}{c}\text { The hierarchy } \\
\text { of the conceptual metamorphosises }\end{array}$} & $\begin{array}{c}\text { The total amount } \\
\text { of the realization }(\%)\end{array}$ \\
\hline 18. & $\begin{array}{c}\text { A DEAD PERSON TURNS INTO A } \\
\text { RESURRECTED PERSON } \\
\text { DEATH AND RESURRECTION CAUSE } \\
\text { METAMORPHOSIS }\end{array}$ & $1(20 \%)$ \\
\hline 19. & $\begin{array}{l}\text { DEATH TURNS INTO AN ABSURD } \\
\text { OPTIMISM CAUSES METAMORPHOSIS }\end{array}$ & $1(20 \%)$ \\
\hline 20. & $\begin{array}{c}\text { A PERSON BECOMES THE PART OF } \\
\text { THE WORLD, } \\
\text { THE WORLD BECOMES THE PART OF } \\
\text { THE PERSON } \\
\text { FEELING CAUSES METAMORPHOSIS }\end{array}$ & $1(20 \%)$ \\
\hline 21. & $\begin{array}{c}\text { AN ALIVE PERSON (A MAN) TURNS } \\
\text { INTO A DEAD PERSON (DUST) } \\
\text { DEATH AND TIME CAUSE } \\
\text { METAMORPHOSIS }\end{array}$ & $1(20 \%)$ \\
\hline \multicolumn{3}{|c|}{ The total amount -5} \\
\hline \multicolumn{3}{|c|}{$\begin{array}{c}\text { Conceptual oxymorons reconstructed } \\
\text { in the British poetical texts of the modern period }\end{array}$} \\
\hline \multicolumn{2}{|r|}{$\begin{array}{c}\text { The hierarchy } \\
\text { of the conceptual oxymorons }\end{array}$} & $\begin{array}{l}\text { The total amount } \\
\text { of the realization }(\%)\end{array}$ \\
\hline 22. & FEET ARE NOT ALIVE & $1(50 \%)$ \\
\hline 23. & ENSIGNS (PEOPLE) ARE NOT MORTAL & $1(50 \%)$ \\
\hline
\end{tabular}

The correlation of the total amount of the conceptual tropes in the macrosegment of the fractal poetical model of the world of the modern period is presented in the following table (table 5).

The hierarchy of the literary concepts identified in the British poetry of the postmodern period that fill the first main circle of the microsegment of the fractal poetical model of the world are presented in the following table (numbers $1-3$ ). The second additional circle is filled by the literary concepts (numbers $4-5$ ). The third additional circle is filled by the literary concepts (numbers $6-14$ ) (table 6). 
The summarizing results

\begin{tabular}{|c|c|c|c|c|}
\cline { 2 - 5 } \multicolumn{1}{c|}{} & $\begin{array}{c}\text { Conceptual } \\
\text { metaphors } \\
(\%)\end{array}$ & $\begin{array}{c}\text { Conceptual } \\
\text { metonymies } \\
(\%)\end{array}$ & $\begin{array}{c}\text { Conceptual } \\
\text { metamorphosises } \\
(\%)\end{array}$ & $\begin{array}{c}\text { Conceptual } \\
\text { oxymorons } \\
(\%)\end{array}$ \\
\hline $\begin{array}{c}\text { The total } \\
\text { amount of } \\
\text { the } \\
\text { conceptual } \\
\text { tropes }(\%)\end{array}$ & $21(72 \%)$ & $1(3 \%)$ & $5(17 \%)$ & $2(7 \%)$ \\
\hline $29(100 \%)$ & & & \\
\hline
\end{tabular}

Table 6

Literary concepts identified in the British poetical texts of the postmodern period

\begin{tabular}{|l|l|l|}
\hline \multicolumn{2}{|c|}{$\begin{array}{c}\text { The hierarchy } \\
\text { of the literary concepts }\end{array}$} & $\begin{array}{c}\text { The total amount } \\
\text { of the realization (\%) }\end{array}$ \\
\hline 1. & DEATH & $7(22 \%)$ \\
\hline 2. & LIFE & $6(19 \%)$ \\
\hline 3. & LOVE & $5(16 \%)$ \\
\hline 4. & TIME & $3(9 \%)$ \\
\hline 5. & PERSONALITY & $2(6 \%)$ \\
\hline 6. & HEART & $1(3 \%)$ \\
\hline 7. & MAGIC & $1(3 \%)$ \\
\hline 8. & MEMORY & $1(3 \%)$ \\
\hline 9. & WOMAN & $1(3 \%)$ \\
\hline 10. & CONDITION & $1(3 \%)$ \\
\hline 11. & OPPONENT & $1(3 \%)$ \\
\hline 12. & PAST & $1(3 \%)$ \\
\hline 13. & SLEEP & $1(3 \%)$ \\
\hline 14. & WORD & $1(3 \%)$ \\
\hline \multicolumn{2}{|c|}{$\begin{array}{c}\text { Numbers } 1-3-18(56 \%) \\
\text { Numbers } 4-5-5(16 \%) . \\
\text { Numbers } 6-14-9(28 \%)\end{array}$} \\
\hline
\end{tabular}

The hierarchy of the conceptual metaphors identified in the British poetry of the postmodern period that fill the first main circle of the macrosegment of the fractal poetical model of the world is presented in the following table (number 1). The second additional circle is filled by the conceptual metaphors (numbers 2 -26) (table 7). 
Conceptual metaphors reconstructed

in the British poetical texts of the postmodern period

\begin{tabular}{|c|c|c|}
\hline & $\begin{array}{c}\text { The hierarchy } \\
\text { of the conceptual metaphors }\end{array}$ & $\begin{array}{c}\text { The total amount } \\
\text { of the realization }(\%)\end{array}$ \\
\hline 1. & DEATH IS THE DANCE & $2(7 \%)$ \\
\hline 2. & A WORD IS A BURNING DREAM & $1(4 \%)$ \\
\hline 3. & LIFE IS A VOYAGE & $1(4 \%)$ \\
\hline 4. & SLEEP IS A DREAM & $1(4 \%)$ \\
\hline 5. & LIFE IS A SLEEP & $1(4 \%)$ \\
\hline 6. & LOVE IS DARK & $1(4 \%)$ \\
\hline 7. & TIME IS VAGUE & $1(4 \%)$ \\
\hline 8. & MIND IS CALM & $1(4 \%)$ \\
\hline 9. & BODY IS THE STORM & $1(4 \%)$ \\
\hline 10. & LOVE IS THE CONDITION & $1(4 \%)$ \\
\hline 11. & LIFE IS A JOURNEY & $1(4 \%)$ \\
\hline 12. & DEATH IS THE END OF A JOURNEY & $1(4 \%)$ \\
\hline 13. & LOVE IS DEATH & $1(4 \%)$ \\
\hline 14. & LOVE IS PAIN & $1(4 \%)$ \\
\hline 15. & LOVE IS TORMENT & $1(4 \%)$ \\
\hline 16. & MEMORY IS THE PATCHWORK & $1(4 \%)$ \\
\hline 17. & LIFE IS WORK & $1(4 \%)$ \\
\hline 18. & LOVE IS A DESEACE & $1(4 \%)$ \\
\hline 19. & LIFE IS A PLAY & $1(4 \%)$ \\
\hline 20. & & $1(4 \%)$ \\
\hline 21. & TIME IS A DESTROYER & $1(4 \%)$ \\
\hline 22. & LIFE IS A DANCE & $1(4 \%)$ \\
\hline 23. & A PERSON IS GOD & $1(4 \%)$ \\
\hline 24. & A PERSON IS A CONTAINER & $1(4 \%)$ \\
\hline 25. & HEART IS A CONTAINER & $1(4 \%)$ \\
\hline 26. & DEATH IS THE SHADOW & $1(4 \%)$ \\
\hline \multicolumn{3}{|c|}{$\begin{array}{c}\text { The total amount }-27 . \\
\text { Number } 1(7 \%) . \\
\text { Numbers } 2-26-25(93 \%)\end{array}$} \\
\hline
\end{tabular}

The second additional circle is filled by the conceptual metonymies (table 8). 
Conceptual metonymies reconstructed in the British poetical texts of the postmodern period

\begin{tabular}{|c|c|c|}
\hline \multicolumn{2}{|c|}{$\begin{array}{c}\text { The hierarchy } \\
\text { of the conceptual metonymies }\end{array}$} & $\begin{array}{c}\text { The total amount } \\
\text { of the realization } \\
(\boldsymbol{\%})\end{array}$ \\
\hline 27. & $\begin{array}{c}\text { THE SHADOW PEOPLE STAND } \\
\text { FOR THE ANCESTORS }\end{array}$ & $1(25 \%)$ \\
\hline 28. & A GHOST STANDS FOR THE WOMAN & $1(25 \%)$ \\
\hline 29. & CLOUDS STAND FOR SOLDIERS & $1(25 \%)$ \\
\hline 30. & DUST OR MUD STAND FOR A PERSON & $1(25 \%)$ \\
\hline \multicolumn{3}{|c|}{ The total amount $-\mathbf{4}}$. \\
\hline
\end{tabular}

The first and the second circles are filled with the conceptual metamorphosises (table 9).

Table 9

Conceptual metamorphosises reconstructed in the British poetical texts of the postmodern period

\begin{tabular}{|c|c|c|}
\hline \multicolumn{2}{|r|}{$\begin{array}{c}\text { The hierarchy } \\
\text { of the conceptual metamorphosises }\end{array}$} & $\begin{array}{c}\text { The total amount } \\
\text { of the realization }(\%)\end{array}$ \\
\hline 31. & $\begin{array}{c}\text { AN ALIVE PERSON TURNS } \\
\text { INTO A DEAD PERSON } \\
\text { DEATH CAUSES METAMORPHOSIS }\end{array}$ & $2(40 \%)$ \\
\hline 32. & $\begin{array}{l}\text { A PERSON TURNS INTO A PRINCE } \\
\text { LOVE CAUSES METAMORPHOSIS }\end{array}$ & $1(20 \%)$ \\
\hline 33. & $\begin{array}{c}\text { A PERSON IS TURNED } \\
\text { INTO AN ANIM AL } \\
\text { MAGIC CAUSES METAMORPHOSIS }\end{array}$ & $1(20 \%)$ \\
\hline 34. & $\begin{array}{c}\text { A CIVILIZATION IS TURNED } \\
\text { INTO NOTHING (DUST) } \\
\text { TIME CAUSES METAMORPHOSIS }\end{array}$ & $1(20 \%)$ \\
\hline \multicolumn{3}{|c|}{ The total amount -5 . } \\
\hline
\end{tabular}

The second additional circle is filled with the conceptual oxymorons (Table 10). 
Table 10

Conceptual oxymorons reconstructed in the British poetical texts of the postmodern period

\begin{tabular}{|c|c|c|}
\hline \multicolumn{2}{|c|}{$\begin{array}{c}\text { The hierarchy } \\
\text { of the conceptual oxymorons }\end{array}$} & $\begin{array}{c}\text { The total amount } \\
\text { of the realization }(\%)\end{array}$ \\
\hline 35. & AN OPPONENT IS NOT AN & $1(50 \%)$ \\
\hline 36. & EVANGELIST & $1(50 \%)$ \\
\hline \multicolumn{2}{|c|}{ A DEAD PERSON IS NOT ALIVE } & The total amount -2 \\
\hline
\end{tabular}

The correlation of the amount of the conceptual tropes representing the macrosegment of the fractal poetical model of the world of the postmodern period is proposed in the table (Table 11).

Table 11

The summarizing results

\begin{tabular}{|c|c|c|c|c|}
\cline { 2 - 5 } \multicolumn{1}{c|}{} & $\begin{array}{c}\text { Conceptual } \\
\text { metaphors } \\
(\boldsymbol{\%})\end{array}$ & $\begin{array}{c}\text { Conceptual } \\
\text { metonymies } \\
(\boldsymbol{\%})\end{array}$ & $\begin{array}{c}\text { Conceptual } \\
\text { metamorphosises } \\
(\boldsymbol{\%})\end{array}$ & $\begin{array}{c}\text { Conceptual } \\
\text { oxymorons } \\
(\boldsymbol{\%})\end{array}$ \\
\hline $\begin{array}{c}\text { The total } \\
\text { amount of } \\
\text { the } \\
\text { conceptual } \\
\text { tropes }(\%)\end{array}$ & $27(71 \%)$ & $4(11 \%)$ & $5(13 \%)$ & $2(5 \%)$ \\
\hline $38(100 \%)$ & & & \\
\hline
\end{tabular}

\section{CONCLUSIONS}

The fractal poetical model of the world is modelled by us on the basis of the British poetry of the $\mathrm{XIX}-\mathrm{XXI}^{\text {st }}$ centuries and our investigation can be perspective because depending on the material of the investigation the fractal model of the world can be constructed not only in the poetry but in the narratology. Thus, the fractal model of the world may be mythological and religious (on the basis of religious and mythological texts), utopian (on the basis of the political texts), historical and philosophical (on the basis of historical and philosophical texts or texts that reflect the historical personality / personalities), futrological (on the basis of the texts of the fantasy genre).

Proposed fractal modelling may be perspective in the investigation of the literary work of a poet, an author, an epoch or poets, authors or different cultural and historical periods. We assume that the fractal model of the world may be semiotical including symbols that can be individual and authors, emphatic, eidetic. In the mathematics and in the geometry, in the existing fractal theory, are identified various types of fractals. It is proved 
that structures the algorithm of the modelling of which is changed spontaneously are superfractals. Multifractals are the complicated fractal structures that consist from several fractal structures. Allatorial fractals fractals in which the smallest outer influence or the outer fluctuations change the form of the whole fractal ${ }^{12}$.

In the linguistic perspective we consider that that the linguistic model may be superfractal segments of which are changed with the integration to the investigation of the text the comparative analysis. The multifractal is the linguistic model that is added by the other linguistic aspect (for example, the combination of the linguistic, the cognitive and the semiotic aspects of the investigation of the texts). The allatorial fractal linguistic model is the model segments of which are changed while the incorporation the new results of the investigation of the text unidentified by the predecessors (e.g., (Fig. 15)).

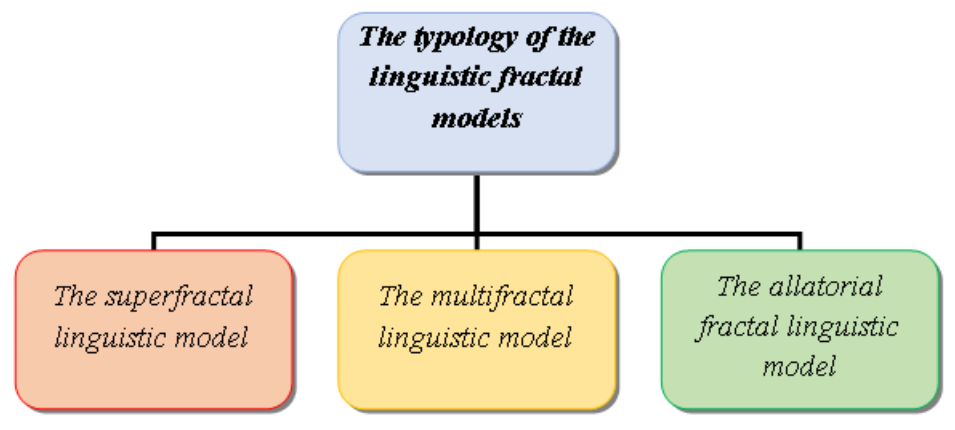

Figure 15. The proposed typology of the linguistic fractal models

The proposed by us methodology of the modelling of the fractal poetical model of the world opens the new paradigm in the modern cognitive linguistics and the cognitive poetics - the cognitive graphics or the cognitive fractal graphics that comprises the combination of the cognitive linguistics, the cognitive poetics, the mathematics, the fractal geometry, the theory of systems, the synergetics. Modelled by us the fractal poetical model of the world is characterized not by the rhizome but the strictly determined structure because the fractal is characterized by the strictly determined structure and consists from the elements of the reductions scale that are selfsimilar and are excelled by the hierarchical organization, by the recursiveness and by the iteration because the process of the fractal modelling is determined by the multifaceted repetition of the analogical

12 Деменок С.Л. Просто фрактал. Санкт-Перербург : Страта, 2018. 308 с. 
mathematical operations - iterations that are recursive, the final element of the fractal is the beginning of the new element - the recursive. Fractal iterations in our process of the design of the fractal poetical model of the world are the linguistic and the cognitive operations and mechanisms that help the linguists to identify literary concepts and to reconstruct conceptual tropes in the text. Recursiveness is the ability of the micro-segment of the fractal poetical model of the world to be transformed into the frame mode, and the macro-segment - into the integrated mode of emergent conceptual blends. The cognitive fractal graphics is proved in the scientific research by the computer design of the fractal poetical model of the world on the basis of the fractal modelling in the mathematics, in the fractal geometry and in the computer graphics.

\section{SUMMARY}

The article is dedicated to the investigation of the specificity of the reproduction of the reality in the fractal poetical model of the world on the basis of the British poetry of the XIX-XXI ${ }^{\text {st }}$ centuries with the help of the linguistic, the poetical analysis of the lexical and the semantic tropes as the verbal means of actualization of cognitive processes of the formation of the fractal poetical model of the world and the outlining of the axiological sense that is specific for the cognitive style of poets of the British romantic, modern and postmodern periods by means of the linguistic, the cognitive, the poetic analyses of the above mentioned tropes. The analyses comprises the usage of the cognitive and the discourse strategies of the interpretation of the deepest sense of the fractal poetical model of the world, such as: the reconstruction of the axiological literary concepts as elements of the fractal poetical model of the world, the modelling of the conceptual tropes as the cognitive basis of the formation and the designing of the fractal poetical model of the world and the modelling of the conceptual blends and frames as emergent cognitive structures of the embodied understanding in the poetics of the British romantic, modern and postmodern periods.

\section{REFERENCES}

1. Бистров Я.В. Біографічний наратив у лінгвокогнітивному вимірі (на матеріалі англомовної прози XX - початку XXI століть) : дис. ... д-ра філ. наук : 10.02.04 ; Київський нац. лінгвістичний ун-т. Київ, 2016. $460 \mathrm{c}$.

2. Деменок С.Л. Просто фрактал. Санкт-Петербург : Страта, 2018. $308 \mathrm{c}$.

3. Деменок С.Л. Суперфрактал. Санкт-Петербург : Страта, 2018. $228 \mathrm{c.}$ 
4. Москвичова О.А. Еволюція метаморфози в англійському поетичному мисленні : монографія. Херсон : Айлант, 2015. 220 с.

5. Blake W. The Selected Poems. London : Wordsworth Poetry Library, 2019. 384 p.

6. Mandelbrot B. B. The Fractal Geometry of Nature. New York : W. H. Freemanand Company, 1982. 470 p.

7. Nikonova V., Boyko Y. Gender-specific emotivity of Victorian female prose from a multidimensional perspective. In Lege artis. Language yesterday, today, tomorrow. 2019. Vol. IV (1). P. 47-82.

Information about the author: Moskvichova O. A., CSc. (Philology), Doctoral Student, Associate Professor at the Department of the English Language and the Methodology of Teaching Kherson State University 27, University str., Kherson, 73000, Ukraine 